\title{
Study on Basic Problems of Socialist Education with Chinese Characteristics
}

\author{
Ping Zhao
}

Nanyang Institute of Technology, Nanyang, Henan, 473000

Keywords: basic problems; socialist education; Chinese characteristics

\begin{abstract}
With the development of the socialist road with Chinese characteristics, China's educational undertakings have also formed an educational line with distinctive socialism. After the founding of New China, China has carried out social reforms. The process of reform is long and arduous. Since the reform and opening-up, China's social and cultural construction and economic construction have developed at a rapid pace. This is an inevitable result of China's development of a socialist development path. Therefore, in the process of developing the road of characteristic socialist education, it is necessary for us to base ourselves on the current national conditions of our country. Based on China's basic national conditions, the development of education will be carried out. For the reform of education, it is essential to combine the basic national conditions of China and the guiding principles for China's future development.
\end{abstract}

\section{Introduction}

The education of ideals and beliefs is the core of ideological and political education, and its effectiveness is related to the success or failure of socialist construction. Strengthening the ideals and beliefs of socialism with Chinese characteristics is based on the realistic needs of social transformation and personal development, and is a powerful spiritual force needed to build up the practice of socialist modernization with Chinese characteristics. The report of the 18th National Congress of the Communist Party of China clearly pointed out that it is necessary to "extensively carry out the education of ideals and beliefs and unite the broad masses of people under the great banner of socialism with Chinese characteristics." Throughout the new changes in the field of social ideals and beliefs in China, how to use Marxist scientific attitude to study, analyze and deeply explore the feasible path of socialist ideals and beliefs education with Chinese characteristics is a new and urgent problem to be solved in the field of ideological and political education. Question.

\section{Problems Existing in China's Current Educational Undertakings}

China's social economy has developed rapidly in recent years, and people's living standards and material and cultural spirits have been improved. Compared with the early days of the founding of the People's Republic of China, China's current level of cultural education has been greatly improved. high. However, in terms of future forms of development, educators are also required to reform education. The overall level of spiritual civilization is the main factor that constrains the development of a country. The country needs to face different problems in different development periods, so it is necessary to carry out deeper reforms in education. At present, China's education is basically divided into three stages: primary school, middle school and university education. Although a few years ago, China proposed to eliminate the school's examination-oriented education, students' education should be developed into a comprehensive development of quality education. However, this situation has not been improved so far, because professional teachers and parents of students support this kind of education model, but in most people, it is considered to be admitted to a prestigious university. In order to find a good job in the future. The purpose of education is actually to improve the overall cultural level of China and cultivate talents for the future development of China. But the original intention of educators is to make educated students pay more attention to the whole process of education, and the test is only a kind of test for themselves. In reality, the position of the two is exactly the opposite. Teachers' parents value the students' 
achievements and regard the test as the goal of learning as the whole future of the students. Educators regard the application as the sole goal of education. This is precisely because of the limitations of people's cognition of education, and the development of China's overall education model is almost a dead end to the test education.

The pursuit of high scores is not uncommon in education. Parents and teachers are always pursuing high scores. In order to make students score higher, they will take the time in class to analyze the questions. The pursuit of high scores will affect the development of students' interests. In education, interest should be regarded as the premise of learning and the development of students' interests should be respected. Students spend a lot of time in school and have a lot of tasks after class. The pressure of students in China's social development has been increasing, and China has made timely adjustments to this phenomenon. As early as a decade ago, the education department had asked educational staff to reduce the burden on students and promote quality education to maintain students' good physical and mental education. However, this phenomenon continues unabated, indicating that there are still major problems in the current education model. This educational concept of the education sector, schools and teachers has not changed. The school has always stressed the need to reform and improve the education level of the school, but mainly in the reform they believe is to improve students' enrollment rate. The problems in education are largely influenced by social issues. The rapid development of the social economy and the increasing social competitiveness have led to the current state of education reform. Parents of teachers hope that students can have a good job in the future and have a bright future. Who will care if it is quality education, and care about the adverse effects of exam-oriented education on children's physical and mental health.

\section{The Development Path of Socialist Education}

The core task of the development of education is how to train students. How to cultivate in a way is especially important for education. With the development of society, there are now many new problems facing the cultivation of young people. For example, the development of the Internet has gradually matured, and there is a lot of harmful information in the Internet, which is extremely unfavorable for the physical and mental development of young people. Therefore, school education units should put the people-oriented education concept first. Taking this as a starting point, the healthy development of students is the primary task, allowing students to eliminate the spread of bad information and establish a solid ideological and moral foundation. Schools should regularly carry out ideological and moral education, focusing on ideological and moral courses, supplemented by ideological and moral activities, and educating students. In recent years, with the deepening of the education work of college students' ideological and political education, college students have greatly improved their political and ideological consciousness, and a group of advanced college student party members have emerged. According to the data, in 2010, the number of new members of the national university students accounted for about $40 \%$ of the national total. Although China's education reform has achieved great achievements, it cannot fully adapt to the current economic development of China. Moreover, the current popularity of education is a certain distance from the goal. This requires a deeper reform of the education industry. In addition to the need to be targeted and people-oriented, the development of China's socialist education path should also carry out innovative reforms in education. We will update the concept of education and carry out innovative reforms in the admissions examination system and the school system. Change the traditional physique assessed by scores, and highlight the importance of the comprehensive development of morality, intelligence, and beauty from the reform of the system.

The innovation of teaching industry is to better cultivate high-quality labor talents for social development, so it is especially important to improve the quality of education. At present, there is a widespread problem in schools that emphasizes the construction of scales in schools and the lack of attention to the quality of teaching. With the convening of the 18th National Congress of the Communist Party of China, the party has comprehensively planned the improvement of the quality of education in China in order to further improve China's education and training system and achieve 
standardization of China's education level. The improvement of the quality of education requires us to innovate the ideas of education, to change the teaching methods of teachers, to focus on students' independent learning ability, to increase the enthusiasm of students in classroom learning, and to improve the quality of teaching in an all-round way. Reasonable allocation of educational resources achieves a relative balance in the overall education of students. Establish a scientific education concept in the school's teaching team. The issue of education has become one of the hotspots of people's livelihood in China. The masses' desire for the quality of education has formed a clear conflict with the allocation of educational resources in China. The improvement of education quality and the fair distribution of educational resources are the primary issues in the current education reform, and also the future development direction of China's education reform road. The responsibility for the fair distribution of educational resources lies in the state and the government, and requires the government to allocate funds for education and the allocation of teachers. Different adjustment policies are proposed for different regions to narrow the gap between urban education and rural education. We will ensure the public welfare of education, encourage the use of social forces to run schools, realize the combination of public and private schools in education, fully integrate the advantages of the two, complement each other's shortcomings, and improve the overall education level. The development of China's characteristic socialist education road is a milestone in China's socialist construction and has far-reaching significance for the future development of China's economic construction. The construction of the characteristic socialist education is proposed by China in accordance with the current national conditions and is to satisfy the huge human resources demand of our country. The development of education has made great progress so far. These effects are obvious. However, it is necessary for educators to carry out more in-depth reforms, analyze and summarize the problems that have arisen on the road to reform, and continuously improve the education system in China. Adhere to the development policy of socialism with Chinese characteristics, thoroughly implement the party's guiding ideology, and transform China from a populous country into a human resource country through the reform of education, and provide more high-quality labor for social development.

From a broader perspective, the so-called socialist theory with Chinese characteristics is essentially guided by the basic principles of scientific socialism, starting from the objective reality of the primary stage of socialism in China, following the universal laws of the development of human society, and exploring a Let China move to the road of human civilization as soon as possible, and make the Chinese nation ahead of the world, and worthy of the title of the ancient civilization. In a word, the research object of the theory of socialism with Chinese characteristics is the regularity of China's construction of a socialist modernization power with relatively backward economic culture. This is not only the research object of the theory of socialism with Chinese characteristics, but also the basic clue that is consistent with the theory of socialism with Chinese characteristics, or the main line. Whether it is Deng Xiaoping Theory, or the important thinking of the "Three Represents", and even the scientific development concept and the construction of a harmonious society, they all answer this question from different angles. Whether it is the answer to "what is socialism, how to build socialism", "what kind of party to build, how to build the party", or the understanding of "what kind of development and how to develop", it also revolves around the economy. The core issue of how China's culturally backward China is building socialist modernization is unfolding. Leaving this main line, it is empty talk.

\section{Conclusion}

Along with the wave of globalization, beliefs, beliefs, and beliefs have become the key words in the field of faith. The emergence of various complicated beliefs has challenged the dominant position of Marxist beliefs. The ideals and beliefs of socialism with Chinese characteristics are an important part of Marxist beliefs. Therefore, the education of ideals and beliefs of socialism with Chinese characteristics is to occupy the highland of belief in Marxist belief education and to show the powerful vitality of Marxism from the front. 


\section{References}

[1] Yuan Guiren. Unswervingly follow the path of China's special color society's education and development [J]. Seeking is, 2012, (12): 20-27.

[2] Zeng Lihong. Historical practice and initiation of education fairness [J]. Education and Occupation, 2007, (35): 30-34

[3] Liu Jin. The Value and Application of Regional History and Culture in the Outline of Modern and Contemporary Chinese History [J]. Research in Ideological Education, 2008, (10).

[4] Zhang Huiling. An Analysis of the Value and Path of the Integration of Shanxi Regional History into the Outline of Chinese Modern and Contemporary History [J]. Educational Theory and Practice, 2011, (7).

[5] Tan Yinghua. An Analysis of the Application of Local Historical and Cultural Resources in the Practical Teaching of the Outline of Modern and Contemporary Chinese History [J]. School Party Construction and Ideological Education, 2012, (10). 